\title{
Editorial \\ Essays in Archaeology and Archaeometry and the Hellenic Contribution to Egyptology
}

\author{
Nikolaos Lazaridis ${ }^{1, *}$, Omar Abdel-Kareem ${ }^{2}\left(\mathbb{D}\right.$ and Grigorios Tsokas ${ }^{3}$ (]) \\ 1 Department of History, College of Arts \& Letters, California State University, Sacramento, CA 95819, USA \\ 2 Conservation, Conservation Department, Faculty of Archaeology, Cairo University, Cairo 12613, Egypt; \\ omaa67@yahoo.com \\ 3 Laboratory of Exploration Geophysics, Department of Geology, School of Geology, Aristotle University of \\ Thessaloniki, GR-541 24 Thessaloniki, Greece; gtsokas@geo.auth.gr \\ * Correspondence: lazaridi@csus.edu
}

check for updates

Citation: Lazaridis, N.;

Abdel-Kareem, O.; Tsokas, G. Essays in Archaeology and Archaeometry and the Hellenic Contribution to

Egyptology. Heritage 2022, 5, 402-408. https://doi.org/10.3390/

heritage 5010023

Received: 18 January 2022

Accepted: 15 February 2022

Published: 22 February 2022

Publisher's Note: MDPI stays neutral with regard to jurisdictional claims in published maps and institutional affiliations.

Copyright: (C) 2022 by the authors. Licensee MDPI, Basel, Switzerland. This article is an open access article distributed under the terms and conditions of the Creative Commons Attribution (CC BY) license (https:// creativecommons.org/licenses/by/ $4.0 /)$.

\begin{abstract}
The contemporary trend of research projects and works are presented on selective issues of archaeometry, archaeology and Egyptology. The current status in research in the area of SE Mediterranean on cultural heritage and archaeological/historical reflections alone and/or coupled with archaeological sciences of eleven papers are placed within an updated frame. The results concern a variety of selected topics critically presented. The topics touch on the cultural astronomy, the ancient textiles and masonries and the physico-chemical and biological investigations, the socio-political issues of Egyptian Ramesside era, revisiting the inscription of an Egyptian statuette, and the valuable information extracted from rock graffiti in north Kharga, Egypt.
\end{abstract}

Keywords: archaeoastronomy; masonry; conservation; embroidery; Coptic; Ramesside; dyes; graffiti; mummy

The interdisciplinary field of Heritage culture, archaeology, history of art, coupled with natural sciences, is undoubtedly a breakthrough in the advancement of cultural heritage studies and sustainability [1,2].

The regional development of heritage studies has begun to attract a great deal of research interest, and SE Mediterranean studies with a focus on Egypt are rich in novel results. Research from these disciplines converge, granting us a higher level of knowledge of heritage from prehistory to historical times. Aspects of tangible and intangible cultural heritage concerning interconnected ancient societies and their activities, development and ingenuity in the SE Mediterranean regions, the cradle of civilizations, are presented in the present volume.

This Special Issue contains eleven articles touching on a variety of selected topics from these subjects; in particular, two on the archaeoastronomy for the earliest mechanical device to the temples at Bekaa, Lebanon; five on the study of dyes in Coptic Textiles and the physico-chemical and biological investigations of ancient textiles and stone masonries and mummies of historic and archaeological significance for conservation purpose; then, a detailed description and interpretation of rare Coptic embroidery traced in the history of art heritage objects; the socio-political issues of the way Egyptians perceived the boundaries of their land and the impact of Egyptian colonialism during the Ramesside period; a reassessment of the inscription of the Egyptian statuette in the Heraklion Archaeological Museum for a more plausible translation; and last, the valuable information extracted from rock graffiti in north Kharga, Egypt.

The Special Issue is made to honor Professor Ioannis Liritzis' for his retirement from the University of the Aegean, Greece- - he is now a distinguished professor at Henan University, China-for his long and prolific academic career which has advanced research in archaeology, cultural heritage and the archaeological sciences, involving multiple initiatives in the archaeology of Egypt (ushering the first chair in Egyptology in University of the Aegean), 
and the wider Eastern Mediterranean archaeology and cultural heritage (www.liritzis.eu, accessed on 2 November 2021; https:/ / archlab.aegean.gr/, accessed on 25 January 2022; https: / / en.wikipedia.org/wiki/Egyptology, accessed on 10 February 2022). Prof. Liritzis' research output refers to a wide spectrum of specialized subjects which are tackled by most of this volume's articles.

Since the early days of mankind, humans have looked to the stars for answers to their biggest questions. The skyscape has been the source of inspiration, imagination, for science and philosophy. The determination of time and identification of human or animal images with them has exerted a strong influence on the human cultures throughout the millennia. The four solar stands, the lunar phases, the planetary orbits, the rise and setting of bright stars and the constellations have triggered past societies to determine the time for daily works. Worldwide examples from the five continents on these aspects are outlined, focusing on the determination of time with solar stands in daylight, the lunar periodic movements, and bright stars and associated configurations (constellations). In essence, the determination of time is deemed necessary for many daily aspects, such as agriculture (sowing, harvesting, cultivation), maritime voyages, rituals and religious festivities, the preservation of the four (climatic) seasons, art, and related myths. In particular, the natural and/or constructed devices in the determination of time and geographical location (sundials, hydraulic and portable devices, topographical markers) including intangible oral documentation of cultural astronomy of aboriginals provides clues on the intangible heritage and other social aspects of the old world [3].

Archaeoastronomy has advanced since the times of the simple and somewhat naïve studies or uncontextualized alignments and can be considered today as a complete, interdisciplinary science tightly connected to cognitive archaeology [4].

Analysis of specific orientations of temples, buildings, altars, natural markers is made to connect them to specific deities, sacred attributes, rites, delivering oracles, major cultural events [4-14] and for the determination of time [15-18].

Concerning the trans-scientific and interdisciplinary approach of conservation science to valuable heritage objects (organic and inorganic origin) and monuments, the current research has produced effective strategies. These follow certain sequential steps; from the characterization of weathering, corrosion and microbial inhibition to development of compatible materials, with emphasis on nanotechnology, to prevent further deterioration and for consolidation to digital recording for museum exhibit. These involves spectroscopic techniques and experimental simulation of aging and conservation tests to define proper materials for conservation. The most significant and most recent contributions have been made to heritage materials of the SE Mediterranean cultures [19-38].

On the history and archaeology side, the tapestry was known as a mirror of civilization, because many tapestries represented scenarios of everyday life. Tapestry may be similar to painting with yarn, depicting an endless picture. The finest articles are seen in Coptic Egypt around the fifth and the sixth centuries A.D. [39]. It became an important issue in the 9th century and later the Iconoclastic controversy in the Near and Middle East and the West, especially during the late Carolingian and Ottonian periods, in a great number of iconographic variations. In some instances, it might be accompanied by the Virgin, St. John, the thieves, or other figures associated with the Passion, recorded on various materials (ivory, wood, textile, stone). Thus, rare objects of that period are of importance in the heritage field of art history and these need proper investigation [39-43].

The socio-political issue of land boundaries was and still is a thorny topic. Egyptians' perception of the boundaries of their land and the Egyptian and colonial encounters has been discussed in the turmoiled region of near East $[44,45]$.

Remoteness in time is one of the main difficulties we encounter when we look for sources of information about the Old Kingdom. Thus, any decipherment of Egyptian hieroglyphic inscriptions are valuable sources of information of past Egyptian dynasties concerning rituals, religion, war affairs, afterlife, etc. [46,47]. 
The valuable information extracted from rock graffiti in Egypt is gaining worldwide attention.

Sites such as Al-Qarta and Abu Tanqoura, north of Komombo town, Nasr Salam, Hula Rock 1 and 2 are ways of communication as texts, images, or signposts, or rock art; they are adding their voices to the muted interactions of all desert travelers who chose to carve messages on such rocks. Whatever these and others in the world mean, these are artistic expressions which bear a message; therefore, it is worthwhile to explore and preserve them [48-54].

In recent years, new research has revived the interest in the unsolved problems posed by the Baalbek monuments, Bekaa Valley, Lebanon. Such problems include dating construction phases, determining relationships with the landscape, and discerning the nature of the cult practiced. In the paper by Magli [55] archeoastronomy is used to suggest that the plan of the Temple of Jupiter was a unified one, conceived under Herod the Great. Magli also argues that the cult was strongly connected to the renewal of seasonal cycles and proves the existence of an orientation custom which appears to originate in Baalbek and to inform all these sacred places.

The earliest mechanical device in the world, dated 2150 years ago, the Antikythera Mechanism found in a shipwreck in the Aegean Sea early 20th century is the oldest extant complex geared device, an amazing analogue computer. The device was operated manually by a user, setting a date in a dial. The intended calculations were made using a set of at least 39 gears while the results were displayed on several scientific scales. This Greek device was used to calculate astronomical phenomena, such as solar and lunar eclipses, constituting confirmation of the written sources regarding the Pan-Hellenic games and the accuracy of its predictions is demonstrable. Efstathiou et al. [56] have developed an application which simulates the exact operation of the physical model of the mechanism. From all the tests that have been performed, it is concluded that the mechanism accurately predicts the astronomical phenomena of the future and confirms with astonishing accuracy the astronomical phenomena of the past.

The role played by the clay minerals and microorganisms in the deterioration process of architectural units is a hot topic in the conservation and restoration of ancient buildings. Building materials (mainly mortars and plasters) from the church of Virgin Mary, Wadi El-Natrun region, Egypt, were examined using spectroscopic techniques (X-ray diffraction, $X$-ray fluorescence and scanning electron microscope with energy dispersive spectroscopy, by Moussa and Roshdy [57]. It was found that wall gypsum mortars in the church contain halloysite as a dominant clay mineral while plaster is clay free; concerning microorganisms, the fungal flora Aspergillus glaucus represent the most dominant fungi.

The assessment, modeling, and strengthening of historic masonry walls of multi-leaf systems essentially require suitable knowledge of their construction technology, typology, geometrical characteristics, and the properties of their components. In this context, a comprehensive structural survey of multiple-leaf walls of medieval historic buildings in Cairo was performed by Amer et al. [58]. Three construction hypotheses of multiple-leaf stone masonry walls are presented considering weak, thick, and monolithic core infill layers. This novel work provided a proper characterization as a prerequisite for determining the most suitable materials and techniques for further strengthening interventions.

Ismael et al. [59] report their research results on the comparative inhibition of three materials of nano zinc oxide (ZnO-NPs), Ceratophyllum demersum and 4-chloro-m-cresol for the microcide on the screaming Mummy in Egyptian Museum store mummies. This screaming mummy suffers from stains due to microbial infection. Microorganisms, isolated from the degraded mummy, were identified with an optical microscope and ribosomal ribonucleic acid (rRNA) analysis to guarantee identification accuracy. Results indicated that the bacteria in the mummy are Bacillus jeotgali, Kocuria turfanensis, Microbacterium imperial, Micrococcus luteus and Bacillus megaterium. Fungi are Monascus pallens and Rhizopus oryzae. The results of minimum inhibitory concentration (MIC) illustrated that the best concen- 
trations for the bio treatment of isolated microorganisms is plant extract (Ceratophyllum demersum) followed by 4-chloro-m-cresol and finally nano zinc oxide.

The research team led by Amer et al. [60] presented further development of multipleleaf stone masonry walls in Egyptian heritage monuments to correctly define the pathology and determine the appropriate interventions for its conservation and preservation. Thus, comprehensive studies on its building materials were carried out implemented to enrich documentation, conservation and restoration issues of this type of wall. The fundamental physical and mechanical properties of the masonry elements were examined by incorporating stone blocks, mortars and core-infill materials utilizing a large range of complementary investigation and analysis techniques, including polarizing microscopy, X-ray diffraction (XRD), thermal analysis (TG/DTA), and environmental scanning electron microscope (ESEM) attached to an EDX unit. The outer leaves of the majority of the multiple-leaf stone-masonry walls in medieval architectural heritage were mainly built of well-dressed limestone blocks with nearly uniform dimensions, while the inner-core layer was usually built of stone-rubble infill with bending lime-based mortar. The uniaxial compressive strengths of core infill and lime-based mortar of the embedded joints are shown to be 85 and $92.5 \%$ lower than the limestone units of the outer layer, respectively. Moreover, experimental observations indicate that the inner core layer exhibits the highest porosity values; consequently, deteriorated, loose and cohesionless core infill could greatly affect the durability and thermal resistivity of this kind of wall. The results provide scientific support for investigating the overall structural behaviour of this type of walls and for decision-making in future conservation and restoration strategies.

Karapanagiotis et al. [61] presented new evidence on the identification of Dyes from twelve ancient Egyptian textiles (4th-5th c. AD) from the Museum of Faculty of Archaeology, Cairo University. Applying high performance liquid chromatography coupled to a diode-array-detector (HPLC-DAD), they investigated samples which were extracted from ancient Egyptian textiles (4th-5th c. AD. They discovered madder, weld (Reseda luteola L.) and indigoid dyes which can be either indigo (Indigofera species and other) or woad (Isatis tinctoria L.). These identifications were achieved, as alizarin, purpurin, rubiadin (madder components), apigenin, luteolin, chrysoeriol (weld components), indigotin and indirubin (indigo/woad components) were detected in the chromatograms of the investigated samples. Additionally, ellagic acid was detected, implying the presence of tannin sources. In some of the studied samples, madder was the only detected dye. It is reported that these samples were treated with a madder source which was rich in purpurin and poor in alizarin. Madder dyes rich in alizarin (probably originated from $R$. tinctorum) were detected only in samples treated with madder-tannin mixtures. Finally, it is noted that the potential use of other madder species (Galium and Asperula species) by the Egyptian dyers cannot be ruled out by the chemical results.

State-of-the-art surface-profiling equipment has been used by Gleeson [62] on the Egyptian statuette, AM Heraklion no. 95, and has established previously unknown hieroglyphic signs, so that the dedicator's second title can now be read, with some confidence, as Maker of the Wadjet Standard.

Lila de Chaves [63] presents the "Crucifixion with the twelve Apostles", a unique Coptic embroidered panel, was on display at the Benaki Museum (Athens, Greece), representing of the "Crucifixion" with Christ in the center and six Apostles on either side, standing next to each other in frontal poses, is quite a rare one. This unique representation of the Crucifixion with the twelve Apostles, which also involves the Ascension, is a one-of-a-kind compositional formula representing Christ's death as a triumph over Death, emphasizing, along with the other factors, its non-Chalcedonic origin. A detailed description and interpretation of the inscription, written in at least three languages. Stylistically, in many details, one can trace Armenian connotations; in addition, there is a Syrian influence especially in the rendering of the Apostles' faces. The inscription constitutes a synthesis of letters from different alphabets. The particular personality of Coptic art prevails, with its abstract, conventional forms and its pronounced mysticism and symbolism, that, nonetheless, remains 
deeply Christian. As for its place of origin, our working hypothesis would assign it to the Low Egypt region of Fayoum dated at the 13th-14th century.

The work of Xekalaki [64] aims to define the way Egyptians perceived the boundaries of their land and reassesses the impact of Egyptian colonialism during the Ramesside period (c. 1292-1069 BCE). During this era, expansive wars, diplomatic action and land administration/governance reforms led Egypt to control a large part of modern Israel, Palestine, Lebanon and Syria. Seeking to explore whether the use of modern terms on ancient Egypt may be an anachronism, this paper reviews the scholarship on (a) Egyptian records documenting conquests and (b) contextual archaeological evidence from the southern Near East itself. This review highlights differences between modern and ancient conceptions of land domination. Finally, Egyptian border-related terms are used in a strictly local symbolic cultural context but not in the one of international diplomacy. As for Egypt's boundary, it was mostly formed as a buffer zone rather than a borderline.

In the course of the last ten years, the North Kharga Oasis-Darb Ain Amur Survey team, led by Salima Ikram (American University in Cairo), has been exploring a network of interconnected desert paths in Egypt's Western Desert, known as Darb Ain Amur. These marked paths run between Kharga Oasis and Dakhla Oasis, linking them to Darb elArbain, a notorious caravan route facilitating contacts between Egypt and sub-Saharan Africa since prehistoric times. Lazaridis [65] reports on two rock graffiti in North Kharga, Egypt, focusing on the types of information one may extract from such ancient epigraphic materials, viewing these as a sustained flow of information between carved messages that probably created a safety net that eased desert travelers' discomfort by making them feel as important contributors to the ongoing efforts to make Western Desert's terrain more hospitable and more navigable.

All the above articles highlight significant novel archaeological and archaeological sciences issues in the SE Mediterranean and Egypt in particular.

Author Contributions: Conceptualization, N.L. and O.A.-K.; methodology, N.L.; O.A.-K., G.T.; software, N.L.; O.A.-K., G.T.; validation N.L.; O.A.-K., G.T.; formal analysis, N.L.; investigation, N.L.; O.A.-K., G.T.; resources N.L.; O.A.-K., G.T.; data curation, N.L.; O.A.-K., G.T.; writing-original draft preparation, N.L.; writing-review and editing, N.L.; O.A.-K., G.T.; visualization, N.L.; O.A.-K., G.T.; supervision, N.L, and O.A.-K.; project administration, N.L.; All authors have read and agreed to the published version of the manuscript.

Funding: This research received no external funding.

Institutional Review Board Statement: Not applicable.

Informed Consent Statement: Not applicable.

Data Availability Statement: Not applicable.

Conflicts of Interest: The authors declare no conflict of interest.

\section{References}

1. Liritzis, I.; Laskaris, N.; Vafiadou, A.; Karapanagiotis, I.; Volonakis, P.; Papageorgopoulou, C.; Bratitsi, M. Archaeometry: An overview. Sci. Cult. 2020, 6, 49-98.

2. Liritzis, I.; Korka, E. Archaeometry's Role in Cultural Heritage Sustainability and Development. Sustainability 2019, 11, 1972. [CrossRef]

3. Liritzis, I.; Vlachos, A. Skyscape Impact to Cultural Astronomy; Liritzis, I., Ed.; Interdisciplinary Essays in Archaeology, Cultural Heritage and Environment, Book Series: Interdisciplinary Contributions to Archaeology; Springer-Nature: Dordrecht, The Netherlands, 2022; in press.

4. Magli, G. Archaeoastronomy. In Introduction to the Science of Stars and Stones; Springer: New York, NY, USA, 2015.

5. Sweatman, M.B.; Tsikritsis, D. Decoding Göbekli tepe with archaeoastronomy: What does the fox say? Mediterr. Archaeol. Archaeom. 2017, 17, 233-250.

6. Lluis i Ginovart, I.; Ugalde-Blázquez, I.; Lluis-Teruel, C. Gisemundus and the orientation of the romanesque churches in the spanish pyrenees (11th-13th centuries). Mediterr. Archaeol. Archaeom. 2021, 21, 205-214.

7. Castro, B.; Liritzis, I.; Nyquist, A. Oracular Functioning and architecture of five ancient Apollo Temples through archaeastronomy: Novel approach and interpretation, Nexus Network Journal. Archit. Math. 2015, 18, 373-395. 
8. Liritzis, I.; Bousoulegka, E.; Nyquist, A.; Castro, B.; Alotaibi, F.M.; Drivaliari, A. New evidence from archaeoastronomy on Apollo oracles and Apollo-Asclepius related cult. J. Cult. Herit. 2017, 26, 129-143. [CrossRef]

9. Liritzis, I.; Castro, B. Delphi and Cosmovision: Apollo's absence at the land of the hyperboreans and the time for consulting the oracle. J. Astron. Hist. Herit. 2013, 16, 184-206.

10. Steiner, G.F. Archaeoastronomy and Bedouin star-lore in the rock art of the Negev desert. Mediterr. Archaeol. Archaeom. 2017, 17, 243-260.

11. Liritzis, I.; Vassiliou, H. Archaeoastronomical orientation of seven significant ancient Hellenic temples. Archaeoastron. Int. 2003, $17,94-100$

12. Munro, A.M.; Gullberg, S.R. Skyscape archaeology as a road to cultural insight. Mediterr. Archaeol. Archaeom. $2018,18,491-497$.

13. Zhang, L. Tomb orientation and posthumous visit to the capital of the supernatural world: The Guo cemetery at Sanmenxia, Henan, China. Mediterr. Archaeol. Archaeom. 2020, 20, 145-161.

14. Liritzis, I.; Vassiliou, H. Does sunrise day correlate with eastern orientation of Byzantine Churches during significant solar dates and Saint's day name? A preliminary study. Byz. Zeitscrift 2006, 99, 523-534.

15. Pliakos, A.A. Are there 12 or 10 the minoan solar 'months'? A reassessment. Mediterr. Archaeol. Archaeom. 2021, 21, 227-236.

16. Pérez-Valcárcel, J.; Pérez Palmero, V. Orientation of the churches in the hispanic medieval castles. Mediterr. Archaeol. Archaeom. 2021, 21, 241-257.

17. Efstathiou, K.; Basiakoulis, A.; Kokkinos, N. Determining the celebration of the next pythian games using the antikythera mechanism, given that they continued to be celebrated non-stop to this day. Sci. Cult. 2022, in press.

18. Voulgaris, A.; Mouratidis, C.; Vossinakis, A.; Bokovos, G. Renumbering of the antikythera mechanism saros cells, resulting from the saros spiral mechanical apokatastasis. Mediterr. Archaeol. Archaeom. 2021, 21, 107-128.

19. Abo-Taleb, T. Documenting oil paintings by fingerprint brushstroke application to antique painting in the Egyptian museum of modern art. Egypt. J. Archaeol. Restor. Stud. 2019, 9, 141-154. [CrossRef]

20. Michalopoulou, A.; Maravelaki, P.; Stefanis, N.A.; Theoulakis, P.; Andreou, S.; Kilikoglou, V.; Karatasios, I. Evaluation of nanolime dispersions for the protection of archaeological clay-based building materials. Mediterr. Archaeol. Archaeom. 2020, $20,221-242$.

21. Alves, C.; Figueiredo, C.A.M.; Sanjurjo-Sánchez, J.; Hernández, A.C. Salt Weathering of Natural Stone: A Review of Comparative Laboratory Studies. Heritage 2021, 4, 1554-1565. [CrossRef]

22. Acri, G.; Testagrossa, B.; Faenza, P.; Caridi, F. Spectroscopic analysis of pigments of the antonello gagini annunciation's sculptural marble group, church of St. Theodore martyr (Bagaladi, reggio Calabria, Italy): Case study. Mediterr. Archaeol. Archaeom. 2020, 20, $1-5$.

23. Capitelli, F.; Dida, B.; Ventura, G.D.; Baldassarre, F.; Capelli, D.; Senesi, G.S.; Mele, A.; Siliqi, D. Functional Nano-Hydroxyapatite for Applications in Conservation of Stony Monuments of Cultural Heritage. Proceedings 2020, 62, 11. [CrossRef]

24. Chyla, J.M. How Can Remote Sensing Help in Detecting the Threats to Archaeological Sites in Upper Egypt? Geosciences 2017, 7, 97. [CrossRef]

25. Hemeda, S.; Osman, T. Impacts of fire on historic stone masonry structures: Physicochemical analysis and application to the al-musafirkhana palace (Cairo). Mediterr. Archaeol. Archaeom. 2021, 21, 191-209.

26. Theologitis, A.; Kapridaki, C.; Kallithrakas-Kontos, N.; Maravelaki-Kalaitzaki, P.; Fotiou, A. Mortar and plaster analysis as a directive to the design of compatible restoration materials in frangokastello (Crete). Mediterr. Archaeol. Archaeom. 2021, 21, 109-120.

27. Amer, O.; Abdel-Aty, Y.; Abd El-Hady, M.; Aita, D.; Torky, A.; Hussein, Y.M. Multiscientific-based approach to diagnosis and characterization of historic stone-masonry walls: The mausoleum of al-imam al-shafi'i, Cairo (Egypt). Mediterr. Archaeol. Archaeom. 2020, 20, 67-82.

28. Arlt, T.; Mahnke, H.E.; Siopi, T.; Menei, E.; Aibéo, C.; Pausewein, R.R.; Reiche, I.; Manke, I.; Lepper, V. Absorption edge sensitive radiography and tomography of Egyptian Papyri. J. Cult. Herit. 2019, 39, 13-20. [CrossRef]

29. Abdallah, M.; Abdrabou, A.; Kamal, H.M. Multiscientific analytical approach of polychrome Greco-Roman palette applied on a wooden model naos: Case study. Mediterr. Archaeol. Archaeom. 2020, 20, 45-65.

30. Ali, M.F.; El-Shafey, H.; Marey Mahmoud, H. Multianalytical techniques of al-bīmāristān al-mu'ayyidi mural painting at historic Cairo: Contribution to conservation and restoration. Sci. Cult. 2021, 7, 33-47.

31. Al-Gaoudi, H.A. Painted ancient Egyptian mummy cloth of khonsuemrenep from bab el-gasus excavation: Scientific analysis and conservation strategy. Sci. Cult. 2020, 6, 49-64.

32. Abdelrahim, S.A.; Elnagar, K. Analytical study and conservation processes of late period limestone canopic jar: Case study. Sci. Cult. 2020, 6, 25-38.

33. Zanini, A.; Trafeli, V.; Bartoli, V. The laser as a tool for the cleaning of Cultural Heritage. IOP Conf. Ser. Mater. Sci. Eng. 2008, 364, 012078. [CrossRef]

34. Mohamed, M.I.; Wael, S.M.; Hamdy, M.M. Experimental study for evaluation of paraloid ${ }^{\circledR}$ B72 and its nanocomposite with nano $\mathrm{TIO}_{2}$ and nano $\mathrm{ZnO}$ for consolidation of pottery samples. Sci. Cult. 2021, 7, 101-111.

35. Borsoi, G.; Santos Silva, A.; Menezes, P.; Candeias, A.; Mirão, J. Analytical characterization of ancient mortars from the archaeological roman site of Pisões (Beja, Portugal). Constr. Build. Mater. 2019, 204, 597-608. [CrossRef]

36. Abdelmoniem, A.M.; Mahmoud, N.; Samaha, S.H.; Mohamed, W.S. Characterization of the best consolidation material for black resin for the late period coffin. Sci. Cult. 2020, 6, 1-7. 
37. Jimenez-Lopez, C.; Jroundi, F.; Pascolini, C.; Rodriguez-Navarro, C.; Piñar-Larrubia, G.; Rodriguez-Gallego, M.; González-Muñoz, M.T. Consolidation of quarry calcarenite by calcium carbonate precipitation induced by bacteria activated among the microbiota inhabiting the stone. Int. Biodeterior. Biodegrad. 2008, 62, 352-363. [CrossRef]

38. Afifi, H.A.M.; Rushdya Rabee, A.H.; Menofy, S.M. An experimental study for consolidation of archaeological cartonnage using klucel $g$ and chitosan, with nanocalcium hydroxide. Sci. Cult. 2021, 7, 49-68.

39. Shailaja, D.; Naik, J.; Wilson, A. Surface Designing of Textile Fabrics; New Age International Pvt Ltd. Publishers: New Delhi, India, 2006.

40. Meinardus, O. The collection of Coptica in the QASR of the Monastery of St. Antony. Bull. Société Archéologie Copte 1980, 18, 272.

41. Schiller, G. Iconography of Christian Art; New York Graphic Society: New York, NY, USA, 1972; Volume 2, pp. $323-324$.

42. Noble, T.F.X. Images, Iconoclasm, and the Carolingians; University of Pennsylvania Press: Philadelphia, PA, USA; Routledge: Oxfordshire, UK, 2021.

43. Karydis, C.; Oikonomou, A.; Konstanta, A. The unpublished Coptic textiles of the monastery of St. John the theologian: Preliminary results of previous alterations and scientific analysis. Mediterr. Archaeol. Archaeom. 2019, 19, $133-142$.

44. Koch, I. Colonial Encounters in Southwest Canaan during the Late Bronze Age and the Early Iron Age; Culture and History of the Ancient Near, East; Frahm, E., Randall, W., Baruch, C., Theo, H., van den Hout, P.J., Winteret, I.J., Eds.; Koninklijke Brill NV: Leiden, The Netherlands, 2021; Volume 119, pp. 1-11.

45. Moreno García, J.C. Recent Developments in the Social and Economic History of Ancient Egypt. J. Anc. Near East. Hist. 2014, 2, 231-261. [CrossRef]

46. Adkins, L.; Adkins, R. The Keys of Egypt: The Obsession to Decipher Egyptian Hieroglyphs; Harper Collin: New York, NY, USA, 2000.

47. Tara, S. Writing the Past: Ancient Egypt through the Lens of Medieval Islamic Thought. In Arabic Humanities, Islamic Thought: Essays in Honor of Everett K. Rowson; Lowry Joseph, E., Toorawa Shawkat, M., Eds.; Brill Academic Pub: Brill Leiden, The Netherlands, 2017.

48. El-Badry, A.E.H.A.; Ali, M.F.; Ismail, B.M. Assessment of the aging treatments of sandstone greywacke rock art (Wadi Hammamat) by petrography, Sem, Xrd, Edx. Sci. Cult. 2019, 5, 37-48.

49. Sternberg, J. Were Indians responsible for all of the peterborough petroglyphs? Sci. Cult. 2019, 5, 61-66.

50. Gingrich, A. Rock art from west and south-west Arabia: Socio-cultural anthropology's insights for the region's eastern transition zones. Mediterr. Archaeol. Archaeom. 2017, 17, 61-73.

51. Bednarik, R.G.; Khan, M. The Rock Art of Southern Arabia reconsidered. Adumatu J. 2009, 20, 7-20.

52. Miqdadi, R.H. ABJAD numerals as an absolute dating method: Forts from al-ain, UAE. Mediterr. Archaeol. Archaeom. 2020, 20, 273-289.

53. Mustafa, M.H. Human or centipede? Egyptian influence on the Nabataean culture. Mediterr. Archaeol. Archaeom. 2019, 19, 39-50.

54. Rzepka, S. Who, Where and Why: The Rock Graffiti of Members of the Deir El-Medina Community; University of Warsaw, Inst of Archaeology, Egypt \& Nubia: Warsaw, Poland, 2014.

55. Magli, G. Archaeoastronomy of the Temples of the Bekaa Valley. Heritage 2021, 4, 1526-1537. [CrossRef]

56. Efstathiou, K.; Efstathiou, M.; Basiakoulis, A.; Kokkinos, N. The Antikythera Mechanism: The Prove of the Accuracy of the Astronomical Calculations Based on It. Heritage 2021, 4, 3848-3878. [CrossRef]

57. Moussa, A.; Roshdy, M. Monitoring Coptic Masonry Affected by Clay Minerals and Microorganisms at the Church of Virgin Mary, Wadi El-Natrun (Egypt). Heritage 2021, 4, 4056-4067. [CrossRef]

58. Amer, O.; Aita, D.; Mohamed, E.K.; Torky, A.; Shawky, A. Multi-Leaf Stone Masonry Walls in Egypt: A Legend. Heritage 2021, 4, 2763-2791. [CrossRef]

59. Ismael, S.; Omar, A.; Maher, M. Comparative Inhibition Study by Nanomaterial, Plant Extract and Chemical Microcide on the Screaming Mummy in Egyptian Museum Store. Heritage 2021, 4, 2481-2493. [CrossRef]

60. Amer, O.; Aita, D.; Mohamed, E.K.; Torky, A.; Shawky, A. Experimental Investigations and Microstructural Characterization of Construction Materials of Historic Multi-Leaf Stone-Masonry Walls. Heritage 2021, 4, 2390-2415. [CrossRef]

61. Karapanagiotis, I.; Abdel-Kareem, O.; Kamaterou, P.; Mantzouris, D. Identification of Dyes in Coptic Textiles from the Museum of Faculty of Archaeology, Cairo University. Heritage 2021, 4, 3147-3156. [CrossRef]

62. Gleeson, L. A Short Note on the Knossos Statuette Inscription. Heritage 2021, 4, 3186-3192. [CrossRef]

63. Lila de Chaves, L. An Investigation on a Coptic Embroidered Panel from the 13th Century "Crucifixion with the Twelve Apostles" (Benaki Museum, Athens). Heritage 2021, 4, 4335-4343. [CrossRef]

64. Xekalaki, G. On Borders and Expansion: Egyptian Imperialism in the Levant during the Ramesside Period. Heritage 2021, 4, 3938-3948. [CrossRef]

65. Lazaridis, N. “Like Wringing Water from a Stone!” Information Extraction from Two Rock Graffiti in North Kharga, Egypt. Heritage 2021, 4, 2253-2260. [CrossRef] 